\title{
Green Business Behaviour, Green Technologies, and Sustainability in SMEs
}

\author{
Submitted 21/12/19, $1^{\text {st }}$ revision 18/01/20, $2^{\text {nd }}$ revision 20/02/20 accepted 10/03/20
}

\author{
Adijati Utaminingsih ${ }^{1}$, Sony Heru Priyanto ${ }^{2}$, \\ John J.O.I. Ihalauw ${ }^{3}$, Linda Kusuma ${ }^{4}$
}

\begin{abstract}
:
Purpose: The purpose of this study is to determine the management and environmentallyfriendly behavior of small-scale aquaculture businesses with emphasis on the institutional environment, entrepreneurial orientation, and green technology.

Design/methodology/approach: The sample consists of 198 respondents in the aquaculturebased SMEs, analyzed with structural equation model (SEM) by using AMOS software.

Findings: The findings show the role of management and business behavior in green business of aquaculture SMEs. This behavior affects the cost and resource efficiency.

Practical implications: The results contribute for SMEs how to manage environmentally friendly businesses through process that encourages environmental governance.

Originality/value: This finding is based on resource based view theory, by identifying and managing the potential resources through green business initiative in SMEs.
\end{abstract}

Keywords: Business management, environmentally friendly technology, entrepreneurial orientation.

JEL code: G34.

Paper type: Research article.

\footnotetext{
${ }^{1}$ Universitas Kristen Satya Wacana, Salatiga, Indonesia, email: adijati@usm.ac.id

${ }^{2}$ President University, Jakarta, Indonesia, email: sonecid@yahoo.com

${ }^{3}$ Universitas Kristen Satya Wacana, Salatiga, Indonesia, email: ihalauw@bundamulia.ac.id

${ }^{4}$ Universitas Kristen Satya Wacana, Salatiga, Indonesia, email:

linda.kusuma@staff.uksw.edu
} 


\section{Introduction}

The adoption of environmentally friendly businesses is the answer to the emergence of various environmental factors institutions, such as government policies, regulations and practices in industry, towards businesses that tend to implement environmental sustainability measures (Hoopes et al., 2003). Jackson and Apostolakou (2010) stated that the institutional environment and managerial characteristics have a significant influence on the behavior of their business environment. It is based on the Resource-Based View (RBV) which is the ability life cycle that comprehensively explains the general pattern of development of organizational capabilities based on dynamic resource.

The results of previous studies also highlight the role of institutional environment in implementing environmentally friendly business (Belal and Cooper, 2011; Pudjiarti and Suharnomo, 2018) to obtain legitimacy that allows organizations to carry out activities in certain ways (Bruton et al., 2010). Jackson and Apostolakou (2010) also show that institutional environmental factors have an influence on efforts to have more environmentally friendly behavior. Moreover, utilizing new technology have a relationship with higher levels of business behavior, and survival rate. Entrepreneurial orientation and business continuity are important to have a significant effect on the innovativevness and resource utilization (Bagheri and Yazdanpanah, 2017; Pudjiarti et al., 2017). This research was conducted on aquaculture-based SMEs in Central Java, having used biofloc technology to maximize productivity in limited land and to utilize organic materials as a means of green business behavior. The research aims to find an aggregative and informative model to examine the improvement of environmentally friendly business of aquaculture-based SMEs. The research is to analyse the influence of the institutional environment on environmentally friendly business behavior through mediating the variables of entrepreneurial orientation and green technologies.

\section{Literature Review}

\subsection{Institution Environment and Green Business Management}

The principle of the institution lays down on the regulatory basis whereby business people try to adjust to existing legality and the aim to increase business opportunities and superior performance (Scott, 2005). Legitimacy allows companies to obtain the right to exist and carry out activities in certain ways (Bruton et al., 2010). One important indicator of the normative view of doing business is the extent to which people value business as a means of creating wealth and providing benefits to society (Le and Nguyen, 2009). Moreover, companies with high entrepreneurial orientation can effectively develop or improve company performance and competitiveness to create opportunities through their actions (Jantunen et al., 2005). Environmentally friendly behavior is very important for business development and continuity to control and allocate resources into environmentally friendly activities 
(Leon and Calvo-Amodio, 2017). Ma and Tan (2006) stated the significant influence of friendly institutional environment on entrepreneurial orientation. Hence, existing technology can be adapted by organizations by implementing business operations processes that are more environmentally friendly, by adapting new technologies to encourage changes in business behavior (Cavalcante, 2014; Thalassinos and Pociovalisteanou, 2009). Leon and Calvo-Amodio (2017) reveal that company technology is a driver of environmentally friendly innovation. Thus, we conclude as:

H1: Institutional environment influences the green business behavior.

H2: Institutional environment influences the entrepreneurial orientation.

H3: Institutional environment influences the green technologies.

\subsection{Entrepreneurial Orientation and Environmentally Friendly Business}

Green behavior refers to the beliefs and intentions associated with green business (Schultz et al., 2004). Stern (2000) stated that business people who tend to have a positive attitude towards the environment will have the desire to adopt and implement environmentally friendly management. The domain of behavior is the environment-friendly behavior of individuals that is determined by beliefs, norms, and personal attitudes towards environmental preservation (Stern et al., 1999).

Companies that develop and integrate environmental problems into the culture of the organization in making decisions, formulating business operations strategies and interacting with stakeholders are deemed to have environmentally friendly business (Linnenluecke and Griffiths, 2010). Implementation of environmentally friendly is to have financial returns (Zwetsloot and Van Marrewijk, 2004). Jantunen et al. (2005) stated that entrepreneurial orientation can create opportunities through action, by reconfiguring dynamic capabilities to improve sustainable business management. Therefore, the next research hypotheses are:

H4: Entrepreneurial orientation influences the green business behavior H5: Entrepreneurial orientation influences the sustainability focus

\subsection{Environmental Friendly Business and Sustainability Focus}

Ferenhof et al. (2014) stated that technology strategies influence organizational behavior competitively to adopt the right technology. Technology strategies are required to establish policies, plans and procedures that help acquire, manage and utilize technology and knowledge to achieve competitiveness. The effect of environmental policy on technology can have substantial implications on policy normative analysis. A flexible and incentive-oriented policy approach is more likely to encourage compliance to change environmentally friendly business behavior (Jaffe et al., 2005). Bagheri and Yazdanpanah (2017) show that there is a significant impact of entrepreneurial orientation on business behavior innovation to adopt environmentally friendly technology in SMEs. Thus, we conclude as: 
H6: Green technologies influence the green business behavior.

H7: Green technologies influence the sustainability focus.

The application of an environmentally friendly technology strategy will encourage organizations to behave and manage businesses competitiveness (Ferenhof et al., 2014) subsequently adopting a proactive environmental strategy reflecting management's commitment to behave in an environmentally friendly business to implement environmentally friendly business management initiatives (Menguc et al., 2010). Therefore, the related hypothesis is as follows:

H8: Green business behavior influences the sustainability focus.

\section{Methodology}

The target population of this study are the owners and entrepreneurs of the aquaculture-based SMEs with an environmentally friendly concept in the catfish cultivation center in Boyolali, Central Java. A total sample of 198 respondents has been used in the empirical part of this study. The method of collecting data was by distributing questionnaires to 270 owners and managers. The sampling technique was by purposive sampling method with judgment sampling. The questionnaire was analysed by using a 9-point Likert scale from 1 (strongly disagree) to 9 (strongly agree). Hypothesis testing uses structural equation modelling (SEM) with AMOS software.

\section{Result}

The results of the goodness of fit index for all the model eligibility criteria showed a chi square value of 207.394 < of the cut value of 213.39 , the probability level is $0.087<0.05$, TLI, CFI, GFI, AGFI all are above 0.9, with CMIN/DF being $1.146<$ 2 , and RMSEA being $0.027<0.08$. These values are declared feasible in determining the goodness of fit (Table 1, Figure 1).

Table 1. Structural model path coefficients

\begin{tabular}{|l|l|l|l|l|}
\hline Path & $\begin{array}{l}\text { Standardized } \\
\text { Estimate }\end{array}$ & S.E & C.R. & P \\
\hline Institution environment $\rightarrow$ Green technology & .213 & .092 & 2.318 & .020 \\
\hline $\begin{array}{l}\text { Institution environment } \rightarrow \text { Entrepreneurship } \\
\text { orientation }\end{array}$ & .206 & .082 & 2.515 & .012 \\
\hline $\begin{array}{l}\text { Entrepreneurship orientation } \rightarrow \\
\text { Environment business behaviour }\end{array}$ & .394 & .089 & 4.418 & $* * *$ \\
\hline $\begin{array}{l}\text { Green tecnology } \rightarrow \text { Environment business } \\
\text { behaviour }\end{array}$ & .233 & .072 & 3.242 & .001 \\
\hline $\begin{array}{l}\text { Institution environment } \rightarrow \text { Environment } \\
\text { business behaviour }\end{array}$ & .248 & .078 & 3.183 & .001 \\
\hline Environment business behaviour $\rightarrow$ & .331 & .093 & 3.560 & $* * *$ \\
\hline
\end{tabular}




\begin{tabular}{|l|l|l|l|l|}
\hline sustainability organization & & & & \\
\hline $\begin{array}{l}\text { Entrepreneurship orientation } \rightarrow \\
\text { Sustainability organization }\end{array}$ & .337 & .092 & 3.669 & $* * *$ \\
\hline $\begin{array}{l}\text { Green tecnology } \rightarrow \text { Sustainability } \\
\text { organization }\end{array}$ & .267 & .073 & 3.668 & $* * *$ \\
\hline
\end{tabular}

Figure 1. Full SEM Model

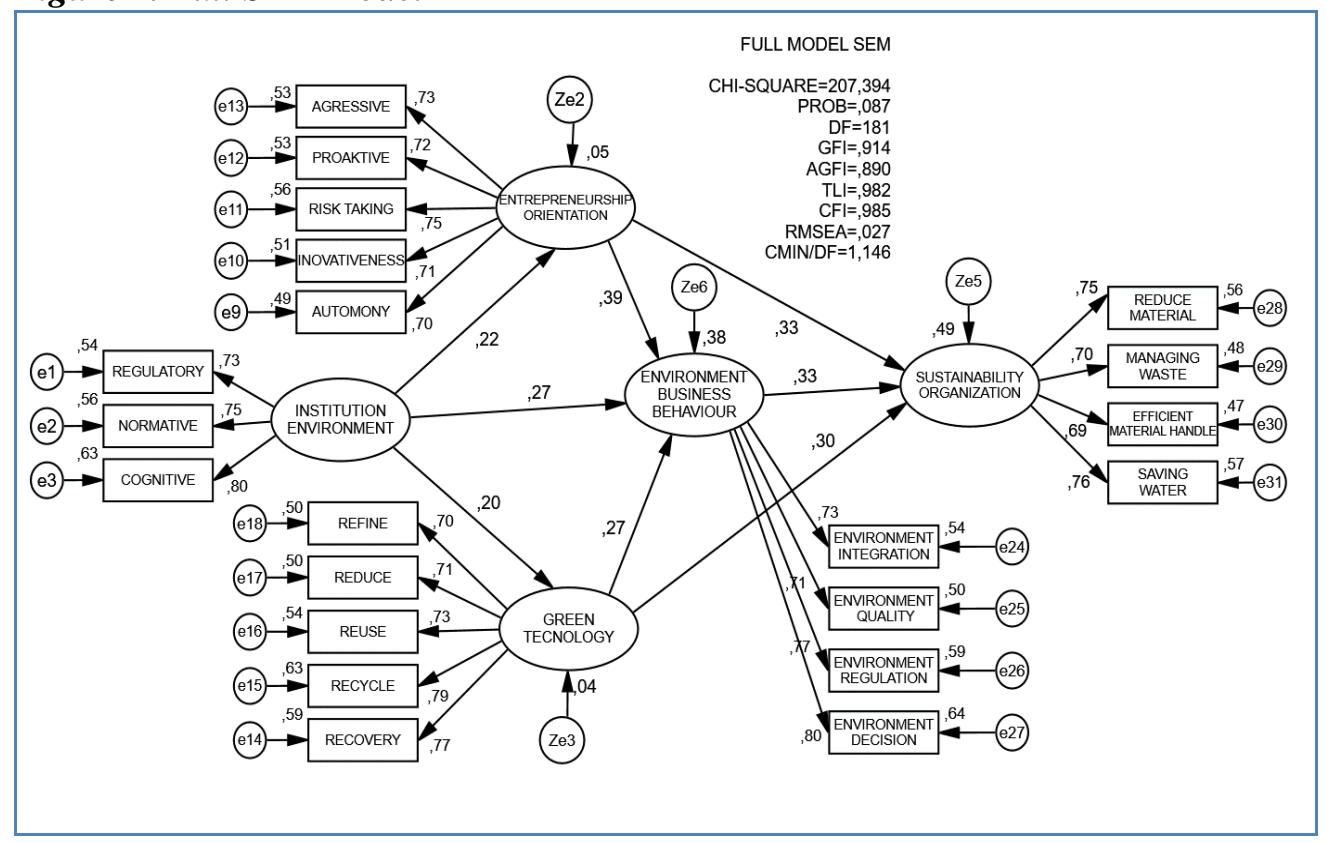

The testing results reveal the influence of the institutional environment on environmentally friendly technologies is proven to be significant with CR of 2.318 (p-value $=.02<.05)$. This study confirms that the higher the institutional environment, the higher the environmentally friendly technology. This study supports Porter and Van der Linde (1995), Hutomo and Pudjiarti (2018) who found that environmental regulations as a form of the institutional environment encourage the application of environmentally friendly technologies.

The statistical analysis of the second hypothesis showed that the institutional environment has significant effect on entrepreneurial orientation with C.R of 2.515 ( $\mathrm{p}$-value $=.12<.05)$. Thus, the higher the institutional environment, the higher the entrepreneurial orientation. The finding is in line with Stenholm et al. (2013) who found that regulations in the institutional environment to promote environmentally friendly activities encourage entrepreneurial orientation. Analysis of third hypothesis found that institutional environment has a significant effect on environmentally friendly business behavior with C.R of 3.183 (p-value $=.001<.05$ ). This means that the higher the level of compliance in the institutional environment the more likely the increase of the environmentally friendly business behavior. 
This is in line with Scott (2005) revealed that the efforts of small businesses to comply with government regulations reinforced by green technology innovations will encourage environmentally friendly business behavior to integrate the reduction of environmental impacts and business quality.

The statistical analysis also show that entrepreneurial orientation has a significant effect on green business behavior with CR 4.418 (p-value $=.000<.05$ ), meaning that the higher the entrepreneurial orientation, the higher the environmentally friendly business behavior. This is in line with Kuckertz and Wagner (2010) who stated that entrepreneurial orientation owned by organizations will shape environmentally friendly business behavior. Moreover, the statistical results show the significant influence of environmentally friendly technology on green business with CR 3.242 (p-value $=.001<.05)$, meaning that the more environmentally friendly technology the more likely to improve the environmentally friendly business behavior. This is supported by Cereola et al. (2012) that existing technology can be adapted to organizations in the environmentally friendly business operation.

The results also showed the significant effect of entrepreneurial orientation on green business with C.R of 3.560 (p-value $=.000<.05$ ), emaing that the higher the level of entrepreneurial orientation, the higher the environmentally friendly businesses. This is in line with Schick et al. (2002) that high entrepreneurial orientation encourages sustainable business management. The testing also show that the significant effect of environmentally friendly technology on green business with CR of 3.560 (p-value = $.000<.05$ ), meaning that the higher the level of environmentally friendly technology is likely to improve the environmentally friendly businesses. This finding was supported by Mason and Spring (2011) that environment-oriented technology can encourage organizations to seek new business opportunities and create customer value.

Lastly, the hypothesis testing also shows the influence of environmentally friendly business behavior on the green business with of CR 3.669 (p-value $=.000<.05$ ), meaning that the higher the application of environmentally friendly business behavior, the higher the environmentally friendly businesses. This finding is consistent with Biryukov and Romanenko (2017) regarding the dynamic relationship between business and institutional behavior to improve the efficiency of business management.

\section{Conclusions}

The findings conclude that the institutional environment significantly influences green business behavior, entrepreneurial orientation and green technologies of aquaculture-based SMEs. Furthermore, the findings also show that entrepreneurial orientation significantly influences green business behavior and sustainability focus. In the context of the influence of technology adoption on green business, the 
findings reveal that green technologies significantly influence green business behavior and sustainability focus. Finally, green business behavior influences significantly on the sustainability focus of aquaculture-based SMEs.

Based on Resource Based View theory, the SMEs' management to maintain competitive advantage in a sustainable manner is more likely to improve the capability in identifying and managing the potential resources through initiative in green business and green technologies and compliant with environment policies. This practically encourage SMEs to manage environmentally friendly businesses through a planning process that encourages the regulation compliance, environmental governance and green technology adoption. The limitations of this study, among others, are that the research model still need to be modified with more specific variables. Future research should explored the alternative constructs such as knowledge, social relations, business collaboration and the role of family business.

\section{References:}

Bagheri, A., Yazdanpanah, J. 2017. Novice Entrepreneurs' Entrepreneurial Self-efficacy and Passion for Entrepreneurship. In Iranian Entrepreneurship, 73-89. Springer, Cham.

Belal, A.R., Cooper, S. 2011. The absence of corporate social responsibility reporting in Bangladesh. Critical Perspectives on Accounting, 22(7), 654-667.

Biryukov, V.V., Romanenko, E.V. 2017. Economic Behavior of Business Entities, Culture and Institutions: Specifics of their Interrelations in Conditions of NeoIndustrialization. European Research Studies Journal, 20(4A), 370-385.

Bruton, G.D., Ahlstrom, D., Li, H.L. 2010. Institutional theory and entrepreneurship: where are we now and where do we need to move in the future? Entrepreneurship theory and practice, 34(3), 421-440.

Cavalcante, S.A. 2014. Preparing for business model change: the "pre-stage" finding. Journal of Management \& Governance, 18(2), 449-469.

Cereola, S.J., Wier, B., Norman, C.S. 2012. Impact of top management team on firm performance in small and medium-sized enterprises adopting commercial opensource enterprise resource planning. Behaviour \& Information Technology, 31(9), 889-907.

Ferenhof, H.A., Vignochi, L., Selig, P.M., Lezana, Á.G.R., Campos, L.M. 2014. Environmental management systems in small and medium-sized enterprises: an analysis and systematic review. Journal of Cleaner Production, 74, 44-53.

Hoopes, D.G., Madsen, T.L., Walker, G. 2003. Guest editors' introduction to the special issue: why is there a resource-based view? Toward a theory of competitive heterogeneity. Strategic Management Journal, 24(10), 889-902.

Hutomo, P.T.P., Pudjiarti, E.S. 2018. Corporate governance and HRM practice on consumption product sector listed in Indonesia stock exchange. European Research Studies Journal, 21(3), 132-142.

Jackson, G., Apostolakou, A. 2010. Corporate social responsibility in Western Europe: an institutional mirror or substitute? Journal of business ethics, 94(3), 371-394.

Jaffe, A.B., Newell, R.G., Stavins, R.N. 2005. A tale of two market failures: Technology and environmental policy. Ecological economics, 54(2-3), 164-174. 
Jantunen, A., Puumalainen, K., Saarenketo, S., Kyläheiko, K. 2005. Entrepreneurial orientation, dynamic capabilities and international performance. Journal of International Entrepreneurship, 3(3), 223-243.

Kuckertz, A., Wagner, M. 2010. The influence of sustainability orientation on entrepreneurial intentions-Investigating the role of business experience. Journal of Business Venturing, 25(5), 524-539.

Le, N.T., Nguyen, T.V. 2009. The impact of networking on bank financing: The case of small and medium-sized enterprises in Vietnam. Entrepreneurship Theory and Practice, 33(4), 867-887.

Leon, H.C.M., Calvo-Amodio, J. 2017. Towards lean for sustainability: Understanding the interrelationships between lean and sustainability from a systems thinking perspective. Journal of cleaner production, 142, 4384-4402.

Linnenluecke, M.K., Griffiths, A. 2010. Corporate sustainability and organizational culture. Journal of world business, 45(4), 357-366.

Ma, H., Tan, J. 2006. Key components and implications of entrepreneurship: A 4-P framework. Journal of Business Venturing, 21(5), 704-725.

Mason, K., Spring, M. 2011. The sites and practices of business models. Industrial Marketing Management, 40(6), 1032-1041.

Menguc, B., Auh, S., Ozanne, L. 2010. The interactive effect of internal and external factors on a proactive environmental strategy and its influence on a firm's performance. Journal of Business Ethics, 94(2), 279-298.

Porter, M., Van der Linde, C. 1995. Green and competitive: ending the stalemate. The Dynamics of the eco-efficient economy: environmental regulation and competitive advantage, 33 .

Pudjiarti, E.S., Suharnomo, S. 2018. Does institutional intervention play a role in small business clustering? An empirical evidence from semarang, Indonesia. Quality Access to Success 19(163), 52-59.

Pudjiarti, E.S., Wahyudi, S., Suharnomo, S. 2017. Organizational learning and lecturer performance: The mediating position of voluntarily creative roles. International Journal of Learning in Higher Education, 24(2), 1-14.

Schick, H., Marxen, S., Freimann, J. 2002. Sustainability Issues for Start-up Entrepreneurs. Greener Management International, (38).

Schultz, P.W., Shriver, C., Tabanico, J.J., Khazian, A.M. 2004. Implicit connections with nature. Journal of environmental psychology, 24(1), 31-42.

Scott, W.R. 2005. Institutional theory: Contributing to a theoretical research program. Great minds in management: The process of theory development, 37(2005), 460-484.

Stenholm, P., Acs, Z.J., Wuebker, R. 2013. Exploring country-level institutional arrangements on the rate and type of entrepreneurial activity. Journal of Business Venturing, 28(1), 176-193.

Stern, P.C. 2000. New environmental theories: toward a coherent theory of environmentally significant behavior. Journal of social issues, 56(3), 407-424.

Stern, P.C., Dietz, T., Abel, T., Guagnano, G.A., Kalof, L. 1999. A value-belief-norm theory of support for social movements: The case of environmentalism. Human ecology review, 81-97.

Thalassinos, I.E. and Pociovalisteanu, M.D. 2009. The Structural Funds and the Economic and Social Cohesion Process. Annals-Economy Series 1, 313-330.

Zwetsloot, G.I.M., Van Marrewijk, M.N. 2004. From quality to sustainability. Journal of Business Ethics, 55(2), 79-82. 